\title{
Editorial Introduction
}

Commodity Frontiers 1, Fall 2020

Mineral Frontiers

The history of the making of the modern world is a history of the expansion of commodity frontiers, a historical process so spatially, socially, and structurally all- encompassing that it still awaits its persuasive analysis. Over the past 600 years, since the inception of the capitalist revolution, these commodity frontiers - processes and sites of the incorporation of resources (land, energy, raw materials, knowledge, and labour) that have shaped the expanding capitalist world economy-have moved at ever accelerating speed across vast areas of the globe, incorporating ever more land, labour and natural resources. Flatlands, valleys, forests, marine spaces and mountains have been farmed, logged, fished, and quarried to provide raw materials and food for a rapidly urbanizing and industrializing global economy, extractive processes that have been crucial drivers of capitalism's expansion (Beckert et al. 2020).

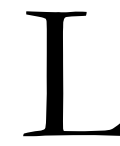

ater this year, the leadership of the

Commodity Frontiers Initiative (CFI)

- Sven Beckert, Ulbe Bosma, Mindi

Schneider, and Eric Vanhaute - will publish an article in the Journal of Global History that outlines our research agenda for studying "Commodity Frontiers and the Transformation of the Global Countryside" from the $15^{\text {th }}$ century up to the present. The lines quoted above open that forthcoming article; they also situate some of the key conceptual and concrete concerns that underlie and motivate our new open-access journal, Commodity Frontiers.

Commodity Frontiers aims to provide robust and freely accessible content on the past,

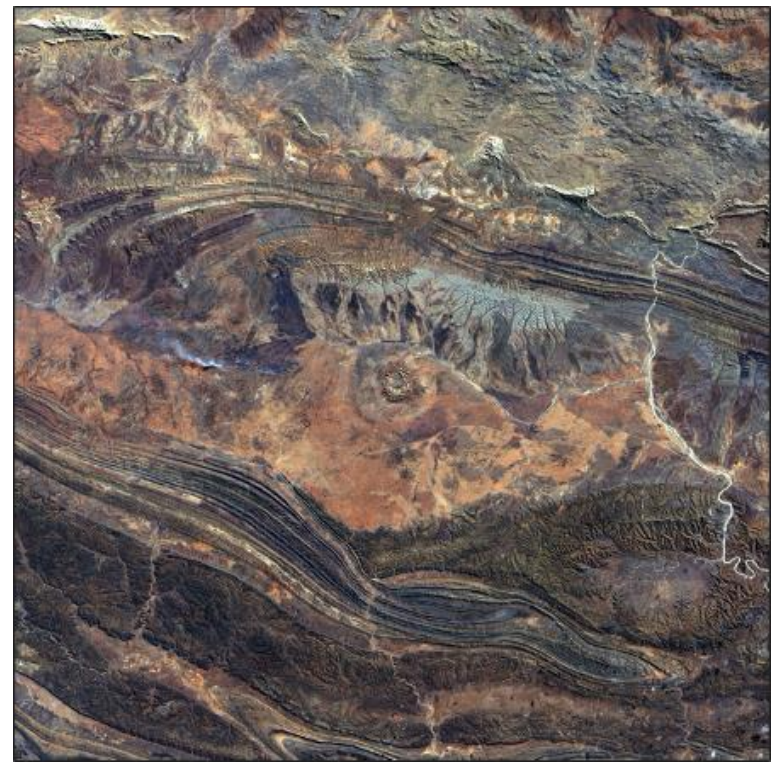

Source: United States Geological Survey (USGS) on Unsplash.

Correspondence:

Mindi Schneider, mindi.schneider@wur.nl

Cite this article:

Schneider, M. 2020. "Editorial Introduction: Mineral Frontiers.” Commodity Frontiers 1: i-iii. doi: 10.18174/CF.2020a17973.

Commodity Frontiers is an open-access journal edited by the CFI Editorial Board, Mindi Schneider, senior editor. Read it online at Commodity Frontiers, or our website, commodityfrontiers.com.

This work is licensed under a Creative Commons Attribution-NonCommercial 4.0 International License. 
present, and future of commodity frontiers, from diverse perspectives and positionalities. We strive for "real-time" reports and reflections on contemporary issues and events, as well as contributions that link the past and present of capitalism and the countryside, providing longer historical viewpoints on problems that are often assumed to be modern.

Commodity Frontiers comprises two themed issues per year, one in the Fall and one in Spring. Each issue includes articles and contributions presented in 11 regularly recurring sections, and every section has its own editorial team. The theme of this, our first issue, is Mineral Frontiers.

As Leonardo Marques states in his contribution, "From smartphones to socalled green technologies, including Elon 'We will coup whoever we want' Musk's electric cars, the production of many contemporary commodities continues to depend on the extraction of various raw materials from different parts of the world" (this issue, p. 48).

Indeed, although we seem to be living in ever-more virtual worlds, with physical distances mediated through digital platforms and devices, our lives are very much embedded in material worlds of objects, "resources" including minerals, and uneven social and ecological relations. A focus on commodity frontiers grounds us not only in these "things," but also in the shared and divergent histories and historical entanglements and conjunctures that produce and reproduce them.

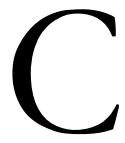
apitalism's commodity frontiers are variously imagined, created, (re)defined, (re)produced, operated, and exploited. They are relocated and shifted, they expand and contract, and they are abandoned. They are colonial, precolonial, and post-colonial. They are places and processes, concrete and abstract.
Commodity frontiers include land, labor, ecological, and technological regimes in particular times and places. They are marked by uneven and shifting power relations between state, business, civil society actors, and financial institutions. And they include and express patriarchal and racialized notions, practices, relations, and structures. Commodity frontiers are rife with inequalities, degradations, and resistances.

As an orienting concept, the commodity frontier lens offers both an entry point and an invitation for depth. Descriptively, the concept helps to document the form and content of commodity frontiers and the dynamics of frontier-ization in particular times and places, without losing sight of more general and shared processes.

Analytically, the lens opens a space for theorizing embodiments of capitalist expansion, including how ecological "limits" (like soil exhaustion) and social contestations (like revolts and protests) underwrite capitalist transformations and flexibility (like spatial and technological fixes). Pedagogically, the commodity frontier offers a connection point between and among researchers, students, and publics, in university, creative, policy, and advocacy/activist spaces.

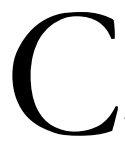
ontributions in this issue take up the commodity frontier lens in various ways. They deal with a range of minerals and frontiers: gold (Engels; Verbrugge and Robles Mengoa), copper (Cottyn), coal (Yeni), lithium (Arndt and Gueye; Cariola; Marquez), "green energy" (Arndt and Gueye; Cariola; Vázquez Ruiz), and seabed and ocean floor mining (Menon). More than this, the articles highlight various approaches to the study of, and engagement with, capitalism's mineral frontiers.

In the opening section, Bettina Engels elaborates the conditions of conflict related to gold mining in Burkina Faso, drawing on her ethnographic research with Kristina Dietz in their GLOCON (Global Change - 
Local Conflict?) research group. Next, Boris Verbrugge and Maria Eugenia Robles Mengoa discuss conceptual, methodological, ethical, and personal challenges of studying global gold mining, including gendered and racialized experiences during ethnographic fieldwork. In her interview with Anna Zalik, Gayatri Menon's article turns to the pedagogy of extraction, offering conceptual insights and inspiration for the classroom, and for linking teaching and research.

Explicitly linking past and present, Hanne Cottyn's article reflects on the "entangled frontiers" of llama herding and copper mining in Bolivia, embedded in histories of capitalism and indigenous resistance, and more recently, in the COVID-19 pandemic. Maria Cariola's piece centers on an interview with members of the highly interdisciplinary Research Group on Commons and Geopolitics at the University of Buenos Aires in Argentina, whose work coalesces around the politics, experiences, and resistances to lithium frontier expansion.

Julien-François Gerber discusses political and conceptual connections between antimining social movements and degrowth, arguing that the two are inexorably linked. Continuing on the theme of conflict and countermovements, Lotte Arndt and Oulimata Gueye's article introduces the transnational artist's collaboration, On-TradeOff, which critically examines extraction, power structures in global capitalism and the global art world, and searches for alternatives. Sithandiwe Yeni's interview with environmental justice and feminist activist, Pinky Langa, details how the
COVID-19 pandemic has impacted women who organize against extractivism in South Africa. And Leonardo Marques reviews two books from 2020 on mining and capitalism, calling for further investigation of how mining changes over time, including in its capitalist forms.

The issue also includes two $O p-E d s$. Ulbe Bosma, the CFI Coordinator, reflects on the WWF's "Living Planet Report 2020" and the long history of capitalism. And Alberto Vázquez Ruiz, Project Coordinator of CATAPA (Belgium), discusses the newly announced (29 September 2020) European Raw Materials Alliance (ERMA) as part of the rise of "green imperialism." Events and Announcements close the issue, with information about relevant workshops, conferences, calls for papers, vacancies, and exhibitions.

Commodity Frontiers is one part of the CFI network and project. Through the pages of this journal, we want to further create and foster community among thinkers and doers who critically engage with commodity frontiers. In these pages we can share perspectives and analyses, data and doubts, reflections and hopes, questions and possible answers. We can exchange ideas, collaborate, and debate. And we can examine the past, while looking to the future.

Mindi Schneider Amsterdam 30 September 2020

\section{References}

Beckert, S., U. Bosma, M. Schneider, and E. Vanhaute. 2020. "Commodity Frontiers and the Transformation of the Global Countryside: A Research Agenda." Journal of Global History (forthcoming). setting up the Online Journal System for Commodity Frontiers. 